Journal of Southeast Asian

2013

\title{
Refugee's Return
}

Anna Nguyen

nguyenwins@gmail.com

Follow this and additional works at: https://docs.lib.purdue.edu/jsaaea

\section{Recommended Citation}

Nguyen, Anna (2013) "Refugee's Return," Journal of Southeast Asian American Education and Advancement: Vol. 8 : Iss. 1, Article 16.

DOI: 10.7771/2153-8999.1071

Available at: https://docs.lib.purdue.edu/jsaaea/vol8/iss1/16

This document has been made available through Purdue e-Pubs, a service of the Purdue University Libraries. Please contact epubs@purdue.edu for additional information.

This is an Open Access journal. This means that it uses a funding model that does not charge readers or their institutions for access. Readers may freely read, download, copy, distribute, print, search, or link to the full texts of articles. This journal is covered under the CC BY-NC-ND license. 


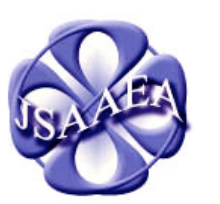

Volume 8 (2013)

\section{Journal of Southeast Asian American Education \& Advancement}

WWW.JSAAEA.org
A peer-reviewed scholarly journal published by the National Association for the Education \& Advancement of Cambodian, Laotian, and Vietnamese Americans (NAFEA)

\title{
Refugee's Return
}

\author{
by \\ Anna Nguyen
}

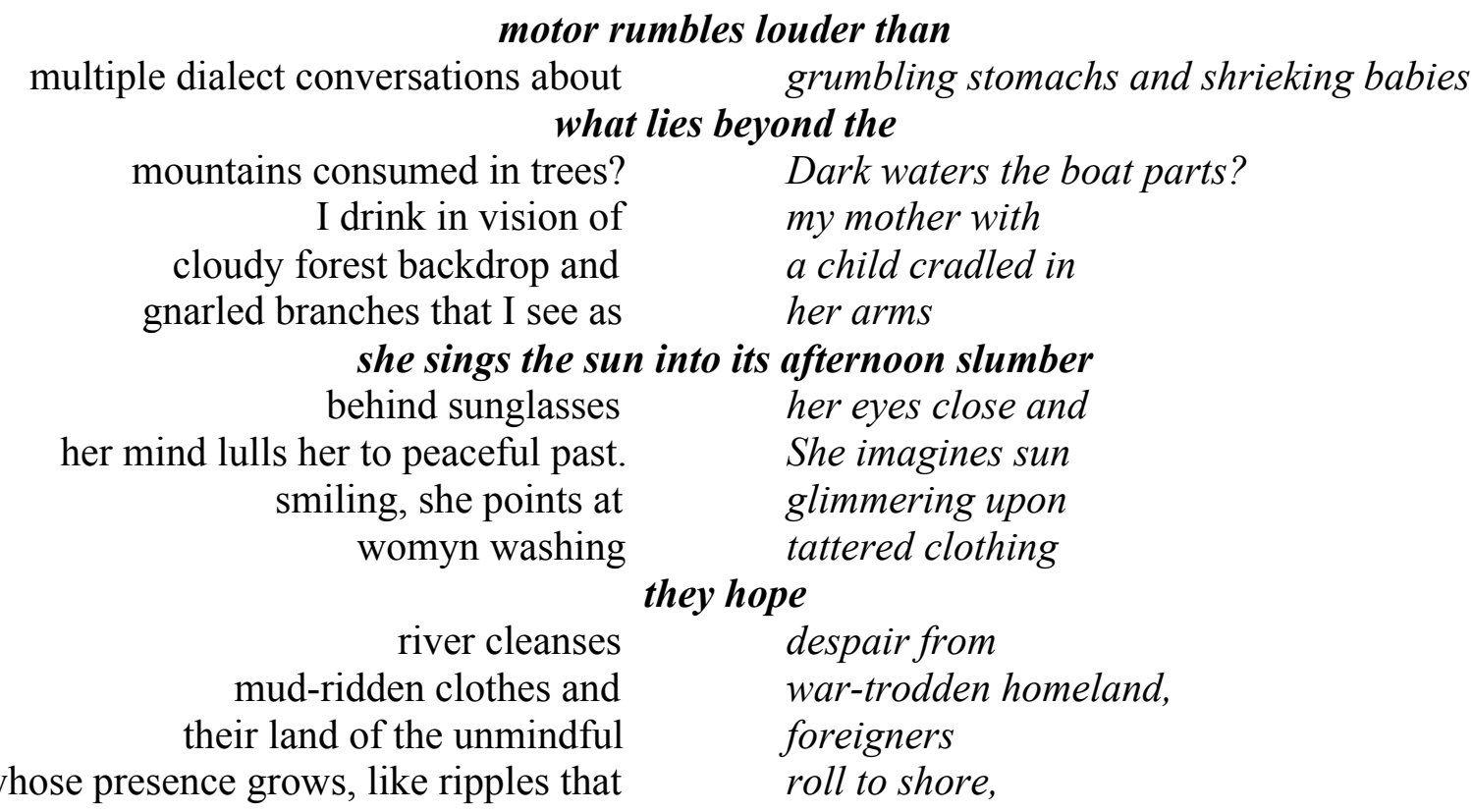

\section{will return no more}

\section{About the Author}

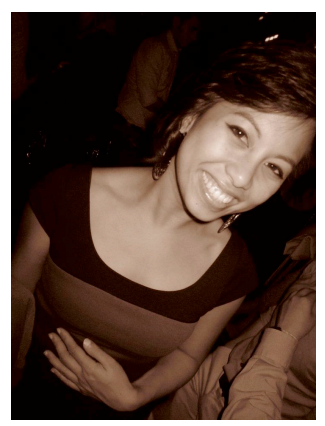

Minh-Giang (Anna) Nguyễn is lecturing at Huế University: College of Foreign Languages under the Fulbright English Teaching Assistantship. She graduated from UC Berkeley with a degree in Sociology and Mass Communications, then she taught fifth grade for three years in East San Jose.

\footnotetext{
(c) SOMERIGHISRESERED Readers are free to copy, display, and distribute this article, as long as the work is attributed to the author(s) and the Journal of Southeast Asian American Education \& Advancement, it is distributed for noncommercial purposes only, and no alteration or transformation is made in the work. More details of this Creative Commons license are available at $\mathrm{http}: / /$ creativecommons.org/licenses/by-nc-nd/3.0/. All other uses must be approved by the author(s) or JSAAEA.
} 


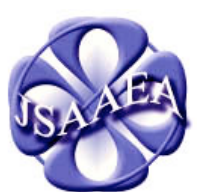

Volume 8 (2013)

\section{Journal of Southeast Asian American Education \& Advancement}

\author{
WWW.JSAAEA.org
}

\section{Editor}

Dr. Wayne E. Wright

University of Texas, San Antonio

\author{
Associate Editors \\ Dr. Chhany Sak-Humphry \\ University of Hawaii at Manoa
}

Dr. Phitsamay Sychitkokhong Uy

University of Massachusetts, Lowell

\section{Book Review Editor}

Dr. Vichet Chhuon

University of Minnesota

\section{Creative Works Editor \\ Bryan Thao Worra \\ Lao Assistance Center}

Special Advisor

Gregory Green

Curator, Echols Collection on Southeast Asia, Cornell University Library

\section{Journal Manager}

Sovicheth Boun

University of Texas, San Antonio
A peer-reviewed scholarly journal published by the

National Association for the Education \& Advancement of Cambodian, Laotian, and Vietnamese Americans (NAFEA)

Comments and questions for the editorial staff may be directed to jsaaea@lists.sis.utsa.edu

\section{Editorial Review Board}

\author{
Dr. Steve Arounsack \\ California State University, Stanislaus \\ Dr. Phala Chea \\ Lowell Public Schools \\ Dr. Loan Dao \\ University of Massachusetts, Boston \\ Dr. Changming Duan \\ University of Missouri, Kansas City \\ Dr. Jeremy Hein \\ University of Wisconsin - Eau Claire \\ Dr. Samlong Inthaly \\ Minneapolis Public Schools \\ Dr. Kevin K. Kumashiro \\ University of Illinois, Chicago
}

Dr. Carl L. Bankston III

Tulane University

Dr. George Chigas

University of Massachusetts, Lowell

Dr. Hien Duc Do

San Jose State University

Dr. Sophal Ear

U.S. Naval Postgraduate School

Dr. Nancy H. Hornberger

University of Pennsylvania

Dr. Peter Nien-Chu Kiang

University of Massachusetts, Boston

Dr. Ha Lam

Arizona State University 

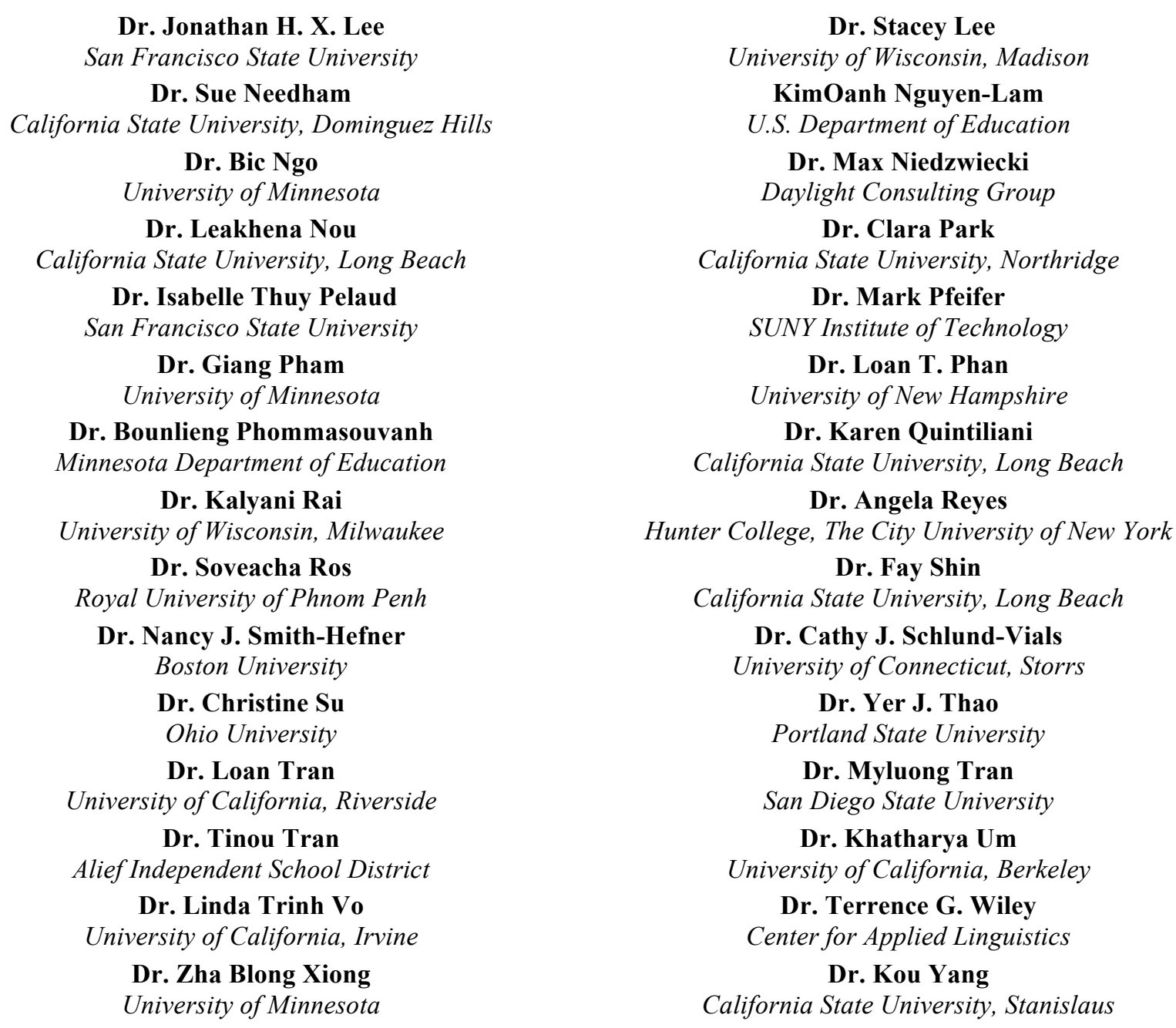

\section{Doctoral Student Editorial Review Board}

Virak Chan

University of Texas, San Antonio

Annie BichLoan Duong

San Joaquin County Office of Education

Peter Tan Keo

Columbia University

Monirith Ly

Texas State University-San Marcos

Hoa Nha Nguyen

University of Minnesota

Vanna Som

Harvard University

Krissyvan Truong

Claremount Graduate University

Yang Sao Xiong

University of California, Los Angeles
Keo Chea-Young

University of Pennsylvania

Ketmani Kouanchao

California State University, Fullerton

Ravy Lao

University of California, Santa Barbara

Thien-Huong Ninh

University of Southern California

Malaphone Phommasa

University of California, Santa Barbara

Alisia Tran

University of Minnesota

Silvy Un

University of Minnesota

Yeng Yang

University of Texas, San Antonio 